ИЗВЕСТИЯ АКАДЕМИИ НАУК ЭСТОНСКОИ ССР. ТОМ ХІV СЕРИЯ ФНЗИКО-МАТЕМАТИЧЕСКИХ И ТЕХНИЧЕСКИХ НАУК. 1965, Na I

\title{
РАЦИОНАЛЬНЫЙ МЕТОД ОЗОЛЕНИЯ СЛАНЦА-КУКЕРСИТА ПРИМЕНИТЕЛЬНО К АНАЛИЗУ ЕГО МИКРОКОМПОНЕНТНОГО COCTABA
}

Определение валового содержания мнкроэлементов в горючих сланцах требует озоления образца. Несмотря на многочисленность исследований $[1,2]$, удовлетворнтельного общего метода для разложения органического вещества пока еше не найдено. В зависимости от свойств материала и определяемых элементов для каждого конкретного случая необходимо подбирать свои специальные условия озоления.

Химико-спектральное определение микроколичеств элементов в горючнх сланцах почти всегда требует озоления больших навесок образцов. Обычно в таком случае прнменяют сухой способ озоления при $450-500^{\circ} \mathrm{C}$, что связано, однако, со многнми трудностями:

1. Озоление в стадии обугливания трудно подвергается контролю аналитнка. Термическое разложение керогена происходит при $200-550^{\circ}\left[{ }^{3}\right]$. Процесс обугливання в пределах $225-250^{\circ}$ протекает медленно, но очень часто сопровождается обнльным выделением летучих и уносом соединений микроэлементов, а также образованием тлеющих, высокотемпературных очагов. Последние возникают в результате случайного перегрева отдельных участков пробы, благодаря малой теплопроводностн керогена. Размеры участков интенсивного окисления все больше расширяются, вызывая быстрое озоление почти всей пробы при высокой температуре. Все это может привести к значительным потерям микроэлементов.

Во избежание описанных вредных явлений навеска сланца должна лежать равномерным слоем толщиной не более $1,5-2$ м.м. Однако это невыгодно для массового анализа, так как в муфельную печь при величине навески 10 г и больше можно поместить только $1-2$ пробы.

2. При температуре $450-500^{\circ}$ углеродистые остатки керогена окисляются медленно. Для полного озоления пробы требуется около восьми часов, что также делает этот метод крайне невыгодным. Кроме того, длительное нагревание пробы может привести к образованию новых, более летучих соединений или трудноразлагаемых силикатов на стенках фарфоровых или кварцевых чашек в результате сплавления окисей металлов и силикатного материала чашки.

Повторная обработка золы азотной кислотой или нитратом аммония с последующим нагреванием до $450^{\circ}$ ускоряет полное озоление пробы, но такой способ не особенно эффективен. При температуре кипения азотной кислоты $\left(121,8^{\circ}\right)$ и температуре разложения нитрата аммония $\left(190^{\circ}\right)$ углеродистый остаток керогена трудно подвергается окислению. Дальнейшее повышение температуры приводит уже к быстрому разложению окислителя, резко уменьшая время воздействия его на углеродистый остаток.

Г. Ринькис [4] разработал ускоренный метод озоления органического вещества с целью колориметрического определения марганца, меди, цинка, кобальта и молибдена в разных биологических объектах. По этому методу пробу сначала обугливают путем ее поджигания, а потом обугленный материал обрабатывают парами азотной кнслоты 
при $400^{\circ} \mathrm{C}$. Полное озоление углерода достигается в течение нескольких минут. Применение методики $\Gamma$. Рннькиса к горючим сланцам в принципе должно дать положительный результат, но оно связано с некоторыми затруднениями:

1) обугливание сланца поджиганием выделяющихся газов и дыма нежелательно, так как сланец горнт сильнокоптящим пламенем, что может вызвать механические потери мнкроэлементов;

2) окончательное озоленне обугленного сланца парами азотной кнслоты пронсходит гораздо медленнее, чем озоление образцов растительного нли животного пронсхождения, изученных Г. Рннькнсом. На его установке трудно организовать одновременное озоленне многнх проб, а обработка каждой пробы сланца в отдельности связана с затратой временн.

Разработанный нами метод озоления горючих сланцев является сочетанием способов мокрого и сухого сжигания керогена. Обугливанне его проводится концентрированной серной кислотой при $160-170^{\circ}$. Окончательное озоление образца достигается обработкой обугленной пробы парами азотной кислоты и окислов азота при $400^{\circ}$.

Особенностью метода является более четкое разделение стадий обугливания органического вещества и полного окисления углеродистого остатка до $\mathrm{CO}_{2}$. Обугливание сланца происходит в интервале температур 160-170 , когда кероген еще термически не разлагается (начало разложения $200^{\circ}$ ). Благодаря эндотермичности процесса выделения воды, образующейся в результате воздействия концентрированной серной кислоты на кероген, температура пробы поддерживается постоянной в пределах $160-170^{\circ}$. Это очень важно для воспроизводимости обугливания проб.

Процесс обугливания керогена с помощью серной кислоты протекает спокойно, без бурного выделения газов разложения. В случае присутствия небольшого избытка серной кислоты дыма вообее не образуется. Проба до окончательного обугливания остается влажной от воды разложения и избытка серной кислоты. Таким образом отпадает опасность уноса некоторой части легких глинистых минералов и керогена вместе с газами разложения.

Обугливание сланца серной кислотой выгодно еще и тем, что в случае присутствия микроэлементов в форме металлоорганических соединений последние, по-видимому, разлагаются в данных условиях о освобождением неорганической части, а не улетучиваются в неразложенном виде вместе с продуктами сухой перегонки керогена, как это происходит при простом сухом озолении.

В связи с потерями микроэлементов необходимо подчеркнуть еще одну особенность данного метода озоления. Обугливание проб, содержащих значительные количества кальцита, с помощью серной кислоты нежелательно, так как образующийся малорастворимый сульфат кальция мешает дальнейшему ходу анализа. Удаление кальцита перед озолением пробы достигается обработкой навески разбавленной азотной кислотой $(1: 5)$. Если эта обработка проводится при температуре, близкой к температуре кипения, вместе с кальцитом растворяются пирит и некоторые другие компоненты минеральной части сланца. В кислотную вытяжку переходит и значительная часть микроэлементов пробы, не проходя стадии озоления. Одновременно удаляются из пробы хлориды, присутствие которых в озоляемом материале нежелательно.

Применение серной кислоты для обугливания сланца связано с некоторой опасностью загрязнения пробы свинцом, цинком и медью, но эта опасность легко устраняется перегонкой кислоты. Кроме того, расход кислоты незначителен: для каждого грамма керогена ее требуется только 
$1-1,5$ мл, в то время как для мокрого озоления необходимы ее десятикратные количества. Содержание свинца, цинка и меди в горючих сланцах настолько высоко, что даже в случае некоторого загрязнения пробы этими элементами от серной кислоты спектральное определение свинца, цинка и меди в концентратах всегда можно провести по менее интенсивным линиям, свободным от влияния загрязнений. Сказанное в полной мере справедливо и по отношению к азотной кислоте, применяемой при озолении, хотя она гораздо чище серной. Постановка слепого опыта все же необходима.

Озоление горючих сланцев происходит следующим образом. ' $\mathrm{K}$ навеске в 10 г в конической колбе добавляют 50 мл азотной кислоты (1:5) и нагревают на плитке в течение 15 мин, не доводя до кйения: Прекращение выделения пузырьков углекислого газа и коричневой двуокиси азота свидетельствует об окончательном растворении кальцита и пирита. Кероген при этом сильно темнеет. Нерастворимый остаток отфильтровывают на воронке Бюхнера диаметром $10 \mathrm{~cm}$. Фильтрат сохраняют, а остаток вместе с фильтровальной бумагой переносят в фарфоровую чашку 3 (см. рисунок), стараясь не разрушить равномерный тонкий слой на бумаге, так как в таком виде он лучше обугливается и озоляется. Затем нерастворимый остаток в чашке обливают концентрированной серной кислотой так, чтобы весь материал был равномерно и полностью смочен (1-1,5 мл на 1 г керогена). Следует избегать боль-

шого избытка кислоты. Затем

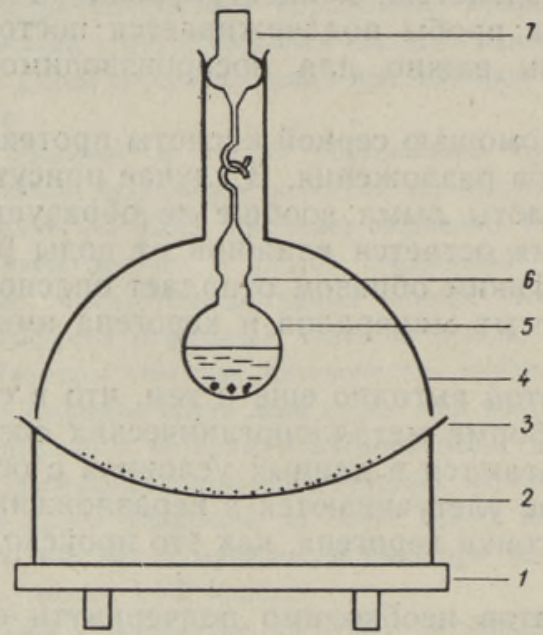

Прибор для озоления горючнх сланцев: 1 электрнческая плитка $(500$ вT); 2 - цилиндр из алюминиевой жести, служащий воздушной баней; 3 - фарфоровая чашка (Ø 13 cм) с пробой; 4 - колпак нз плоскодонной колбы с отрезанным дном; 5 - колбочка $(50-100$ мл) с азотной кислотой и кусочками пористого стекла; 6 -- отверстия для выхода паров кислоты; 7 - пробка с крючком. чашку ставят на воздушную баню 2. В течение 30 мин температуру бани поддерживают в пределах $250^{\circ}$, регулируя нагрев плитки 1 реостатом или автотрансформатором. В это время происходит обугливание керогена. Высыхание влажной черной массы и отделение ее от стенок чашки свидетельствует об окончании обугливания. Выведением реостата поднимают температуру бани до $400^{\circ}$ и приступают к обработке обугленной пробы парами азотной кислоты. В колбочку 5 бросают несколько кусков сухого пористого стекла (от стеклянных фильтров) и наливают 2025 мл концентрированной азотной кислоты. Колбочку подвешивают к крючку пробки 7 и покрывают чашку 3 колпаком 4. Через несколько минут кислота в колбочке вскипает за счет тепла, передаваемого чашке и воздуху под колпаком oт воздушной бани. Во избежание внезапного бурного закипания кислоты каждый раз в начале озоления вместе с кислотой следует прибавлять пару новых кусочков сухого пористого стекла, так как кусочки, поры которых заполнены кислотой, не предотвращают толчков при вскипании. В течение $20-30$ мин происходит полное окисление углеродистого остатка пробы. Для ускорения озоления желательно, припод- 
няв колпак, осторожно перемешивать пробу стеклянной палочкой $1-2$ раза.

Описанная установка является своего рода печью, наполненной парами азотной кислоты и окислов азота. Окисление углерода до $\mathrm{CO}_{2}$ происходит равномерно по всей пробе при относительно низкой температуре $\left(400^{\circ}\right)$. Образования высокотемпературных тлеющих очагов, столь характерных для озоления пробы на воздухе, здесь не наблюдается. Постоянная атмосфера пгаров азотной кислоты и окислов азота создает благоприятные условия для образования окислов, летучесть которых относительно низка.

\begin{tabular}{l|c|c|c}
\hline \multirow{2}{*}{$\begin{array}{c}\text { Эле- } \\
\text { мент }\end{array}$} & Введено & Найдено & Разница \\
\cline { 2 - 4 } & \multicolumn{3}{|c}{$\%$} \\
\hline & \multicolumn{2}{|c}{$\%$} \\
$\mathrm{As}$ & $3,0 \cdot 10^{-3}$ & $2,7 \cdot 10^{-3}$ & $-10,0$ \\
$\mathrm{Sb}$ & $3,0 \cdot 10^{-3}$ & $3,2 \cdot 10^{-3}$ & $+6,7$ \\
$\mathrm{~Pb}$ & $5,0 \cdot 10^{-3}$ & $4,6 \cdot 10^{-3}$ & $-8,0$ \\
$\mathrm{Ga}$ & $3,0 \cdot 10^{-3}$ & $3,3 \cdot 10^{-3}$ & $+10,0$ \\
$\mathrm{Ni}$ & $5,0 \cdot 10^{-3}$ & $5,4 \cdot 10^{-3}$ & $+8,0$ \\
$\mathrm{Co}$ & $3,5 \cdot 10^{-3}$ & $3,9 \cdot 10^{-3}$ & $+11,4$ \\
$\mathrm{Mo}$ & $3,0 \cdot 10^{-3}$ & $3,3 \cdot 10^{-3}$ & $+10,0$ \\
$\mathrm{Cu}$ & $3,0 \cdot 10^{-3}$ & $3,1 \cdot 10^{-3}$ & $+3,3$ \\
$\mathrm{Ag}$ & $1,0 \cdot 10^{-3}$ & $1,1 \cdot 10^{-3}$ & $+10,0$ \\
$\mathrm{Zn}$ & $3,0 \cdot 10^{-2}$ & $3,2 \cdot 10^{-2}$ & $+6,7$ \\
$\mathrm{Sn}$ & $4,0 \cdot 10^{-3}$ & $4,3 \cdot 10^{-3}$ & $+7,5$
\end{tabular}

Для проверки данного метода до озоления в пробы горючих сланцев вводились добавки элементов в виде нитратов. Зола этих проб подвергалась количественному спектральному анализу, квадратичная ошибка воспроизводимости которого составляет $\pm 10-12 \%$. Количества добавленных до озоления элементов сравнивались с количествами тех же элементов в контрольных пробах, куда добавки были введены после озоления.

Результаты проверки приведены в таблице. Содержание элементов дано в процентах по отношению к исходной навеске горючих сланцев и является средним из 10 параллельных определений.

Поскольку разница между введенными и найденными количествами элементов не превышает ошибки воспроизводимости спектрального анализа, в настоящее время нам трудно указать на причины этих расхождений, хотя для конкретного элемента они оказались либо отрицательными (мышьяк, свинец), либо положительными (остальные элементы таблицы). Приведенные данные все же позволяют сделать вывод о том, что озоление горючих сланцев согласно данной методике не оказывает существенного влияния на результаты спектрального определения вышеуказанных микроэлементов.

ЛИТЕРАТУ Р А

1. Middlet on G., St yckey R. E., Analyst, 78, 532 (1953).

2. Schulek E., Laszlovszky J., Mikrochim, acta, Nr. 4, 485 (1960).

3. Справочник по переработке горючих сланцев, Гостоптехиздат, Л., 1963.

4. Р инькис Г. Я., Методы ускоренного колориметрического определения микроэлементов в биологических объектах, Рига, 1963.

Ннститут геологии

Академии наук Эстонской ССР

Поступила в редакцию

24/XII 1964 
E. JOHANNES, A. MILLER

\section{RATSIONAALNE MEETOD KUKERSIIDI TUHASTAMISEKS TEMA MIKROKOMPO- NENTSE KOOSTISE MAX̃RAMISE EESMÃRGIL}

Eesti pōlevkivis leiduvate $\mathrm{As}, \mathrm{Sb}, \mathrm{Pb}, \mathrm{Sn}, \mathrm{Ga}, \mathrm{Ni}, \mathrm{Co}, \mathrm{Mo}, \mathrm{Cu}, \mathrm{Ag}$ ja $\mathrm{Zn}$ mikrohulkade keemilis-spektraalseks määramiseks töötati välja tuhastamismeetod. See seisneb pōlevkivi kerogeeni esialgses söestamises vähese hulga kontsentreeritud väävelhappega, millele järgneb tuhastamine lämmastikhappe aurudega $400^{\circ} \mathrm{C}$ juures. Tuhastamiseks valmistati seadis, mis vōimaldab samaaegselt tuhastada paljusid proove. Tuhastamiseks kulub. 60 - $80 \mathrm{~min}$, kuna tavaline kuivtuhastamine muhvelahjus $450-500^{\circ}$ juures kestab vähemalt 8 tundi.

\section{E. JOHANNES, A. MILLER}

\section{RATIONELLE BRENNSCHIEFERASCHE-GEWINNUNG ZWECKS BESTIMMUNG. DER MIKROKOMPONENTE DES BRENNSCHIEFERS (KUKERSITS)}

Zur chemisch-spektrographischen Bestimmung von Mikromengen der Elemente As, $\mathrm{Sb}, \mathrm{Pb}, \mathrm{Sn}, \mathrm{Ga}, \mathrm{Ni}, \mathrm{Co}, \mathrm{Mo}, \mathrm{Cu}, \mathrm{Ag}, \mathrm{Zn}$ im estnischen Brennschiefer wurde eine Veraschungsmethode ausgearbeitet. Sie besteht aus einer einleitenden Verkohlung des, Kerogens des Brennschiefers mit einer geringen Menge konzentrierter Schwefelsäure und. aus einer darauffolgenden Veraschung des verkohlten Materials im Dampfe der Salpetersäure bei $400^{\circ} \mathrm{C}$. Die entsprechende Apparatur ermöglicht es, mehrere Proben gleichzeitig zu veraschen.

Die Veraschung dauert $60-80$ Minuten, während die gewöhnliche Trockenveraschung im Mufíelofen bei $450-500^{\circ}$ wenigstens 8 Stunden beansprucht. 